8. Dresser, D. W., Keeler, K. D. \& Phillips, J. M. Biochem. Soc. Trans. 4, 34-38 (1976)

Taylor-Upsahl, M. M., Abrahamsen, T. G. \& Natvig, J. B. Clin. exp. Immun. 28, 197-203 (1977).

10. Dresser, D. W. in Handbook of Experimental Immunology (ed. Weir, D. M.) Ch. 28 (Blackwell, Oxford, 1978).

11. Cohn, E. J. et al. J. Am. chem. Soc. 68, 459-475 (1946).

12. Plotz, P. H., Talal, N. \& Asofsky, R. J. Immun. 100, 744-751 (1968).

13. Mandy, W. J., Fudenberg, H. H. \& Lewis, F. B. J. Immun. 95, 501-509 (1966)

14. Johnson, P. M. \& Page-Faulk, W. Clin. Immun. Immunopath. 6, 414-430 (1976).

15. Elson, C. J., Naysmith, J. D. \& Taylor, R. B. Int. Rev. exp. path. 19 (in the press).

16. Parkhouse, R. M. E. \& Dresser. D. W. in The Secretory Immune System and Caries Immunity (eds McGhee, J. R. \& Mestecky, J.) (Plenum, New York, 1978).

17. Metzger, H. in Tolerance, Autoimmunity and Aging (eds Sigel, M. M. \& Good, R. H.) 120-126 (C. C. Thomas, Springfield, Illinois, 1972).

18. Kay, M. M. B. Proc. natn. Acad. Sci. (U.S.A.) 72, 3521-3535 (1975).

19. Najiar, V. A. Lymphology 3, 23-31 (1970).

20. Weigle, W. O. Clin. exp. Immun. 9, 437-477 (1971).

21. Fudenberg, H. H. Am. J. Med. 51, 295-298 (1971)

22. Gershon, R., Cohen, P., Hencin, R. \& Liebhaber, S. J. Immun. 108, 586-590 (1972).

23. Cunningham, A. J. Nature 254, 143-144 (1975)

24. Jerne, N. K. Ann. Immun. Inst. Pasteur 125C, 373-389 (1974)

25. Jerne, N. K. Eur. J. Immun. 1, 1-9 (1971).

26. Dresser, D. W. Br med. Bull. 32, 147-151 (1976).

-

\section{High proportion of Ig-producing cells making autoantibody in normal mice}

'NATURAL' serum antibodies are thought to arise as a result of stimulation by environmental antigens. Evidence suggests, however, that many such antibodies in normal healthy individuals are specific for and may be induced by a variety of self components. Many of these autoantibodies are directed against 'buried' or 'enzyme-revealed' self antigens and include those specific for mouse reproductive organs which crossreact with human group A erythrocytes ${ }^{1}$, human and rabbit immunoglobulins treated with proteolytic enzymes ${ }^{2,3}$, denatured $\mathrm{DNA}^{4}$, enzyme-treated human lymphocytes and erythrocytes ${ }^{5-8}$, and mouse erythrocytes treated with the proteolytic enzyme bromelain?. This widespread occurrence of autoantibodies could suggest that the normal immune system is preoccupied in reacting against self antigens. One way of measuring the extent of this reactivity is to compare the number of B cells making a given autoantibody(s) with the total number of B cells producing immunoglobulin (Ig) irrespective of specificity. We have previously shown that normal conventional and germ-free mice possess in their spleens considerable numbers of PFC against bromelain-treated isologous mouse erythrocytes (BrM), an 'internal' antigen of mouse erythrocytes ${ }^{9,10}$. We have measured the proportion of Ig-secreting cells in the lymphoid organs of normal CBA/ $\mathrm{H}$ mice forming PFC against $\mathrm{BrM}$ and found that in some (but not all) major lymphoid organs between $1 \%$ and $>50 \%$ of the existing or potential Ig-secreting cells are specific for $\mathrm{BrM}$.

All PFC assays were carried out using the liquid monolayer system of Cunningham and Szenberg ${ }^{11}$. Bromelain-treated mouse erythrocytes were used to detect BrM PFC (ref. 10). Ig-secreting cells (Ig PFC) were detected by the reverse plaque method $^{12}$ using sheep erythrocytes coated with. the globulin fraction of a polyvalent hyperimmune sheep anti-mouse Ig serum by the chromium chloride method ${ }^{13}$. Reverse plaques require the presence of a rabbit anti-mouse Ig-developing serum at about the same concentration as used to detect conventional specific indirect plaques (see ref. 14). The detection system is polyvalent, revealing B cells producing IgM, IgG and IgA (data not shown). The direct BrM PFC are formed by cells making IgM antibody. Thus, the 'true' proportion of BrM PFC to total IgM PFC will be greater than the frequencies reported here if significant numbers of cells secreting Ig classes other than IgM are present in a given organ.

The numbers of BrM PFC and Ig PFC in various organs of CBA/H mice are shown in Tables 1 and 2 . Table 1 displays the 'natural' antibody producers in freshly collected cell suspensions, whereas Table 2 shows results for cells cultured for several days in the presence of lipopolysaccharide (LPS)-a polyclonal B cell activator ${ }^{15}$ - to identify 'potential' antibody producers.
The spleens of normal male or female $\mathrm{CBA} / \mathrm{H}$ mice contain about $5,700 \mathrm{Ig}$ PFC per $10^{6}$ cells (Table 1). Ig PFC are also found in other lymphoid organs, notably mesenteric lymph nodes $\left(3,000 / 10^{6}\right)$, bone marrow $\left(1,030 / 10^{6}\right)$, thymus $\left(310 / 10^{6}\right)$ and Peyer's patches $\left(15,000 / 10^{6}\right)$. Few are present in popliteal and parathymic lymph nodes or in freshly collected peritoneal or pleural cavity cells. BrM PFC have a different distribution. Expressed as a percentage of Ig PFC, BrM PFC are high in spleen $(1.6 \%)$ and bone marrow $(7.4 \%)$, low in thymus $(0.6 \%)$ and mesenteric lymph nodes $(0.2 \%)$ and undetectable in Peyer's patches $(<0.01 \%)$.

If peritoneal cells are cultured in vitro they can be shown to rapidly produce many BrM PFC (refs 16 and 17). It has been shown that the appearance of BrM PFC in peritoneal (and spleen) cell cultures requires little cell division but does depend on RNA and protein synthesis ${ }^{16}$. The mechanism of the normal in situ suppression of these potential PFC is not clear, although there is some evidence that an antigen dependent blockading process is involved ${ }^{18}$.

The large number of $\mathrm{BrM}$ PFC generated in short-term peritoneal cell cultures suggested that much of the Ig-secreting cell potential in this site may be directed against BrM. Table 2 summarises results of a series of experiments comparing the proportions of BrM and Ig PFC after short-term culture in the presence of LPS. For spleen 1-2\% of Ig PFC were BrM specific (same as before culture, Table 1). Peyer's patch cells, containing few BrM PFC before culture (Table 1), also show very low numbers after culture. Parathymic lymph nodes behave similarly in this respect (data not shown). The most striking result occurs in cultures of peritoneal or pleural cavity cells, where between $40 \%$ and $95 \%$ of the Ig PFC are BrM specific. It is noted that older mice, particularly retired breeder females contain more potential PFC than younger mice. Lord and Dutton ${ }^{16}$ have reported no increase with age in the number of BrM PFC generated by peritoneal cells in vitro. Our findings agree, however, with earlier studies by Nossal et al. ${ }^{19}$ who showed that peritoneal cell cultures from retired breeder females produce many more PFC against sheep erythrocytesan antigen known to crossreact with $\mathrm{BrM}^{17.18}$ - than young male mice.

In other experiments (data not shown) we have shown that removing cells forming rosettes with $\mathrm{BrM}(1 \%$ in spleen, $20 \%$

Table 1 Tissue distribution of Ig-secreting cells and BrM PFC in $\mathrm{CBA} / \mathrm{H}$ mice*

\begin{tabular}{|c|c|c|c|}
\hline \multicolumn{4}{|c|}{ PFC per $10^{6}$ cells } \\
\hline & Ig & BrM & $\% \mathrm{BrM} \dagger$ \\
\hline Spleen & $5,700 \pm 350 \ddagger$ & $87 \pm 17 \ddagger$ & $1.6 \pm 0.4 \ddagger$ \\
\hline Thymus & $310 \pm 150$ & $1.4^{-} 1.1$ & $0.6 \pm 0.2$ \\
\hline $\begin{array}{l}\text { Parathymic lymph } \\
\text { nodes }\end{array}$ & $180 \pm 48$ & $5 \pm 3$ & $2.2 \pm 1.2$ \\
\hline $\begin{array}{l}\text { Mesenteric lymph } \\
\text { nodes }\end{array}$ & $3,000 \pm 830$ & $7 \pm 4$ & $0.2 \pm 0.1$ \\
\hline $\begin{array}{l}\text { Popliteal lymph } \\
\text { nodes }\end{array}$ & $38 \pm 21$ & $\leq 14$ & \\
\hline Bone marrow & $1,030 \pm 370$ & $70 \pm 22$ & $7.4 \pm 0.7$ \\
\hline Peyer's patches & $15,000 \pm 3,400$ & $<1$ & $<0.01$ \\
\hline Peritoneal cells & $250 \pm 190$ & $42 \pm 24$ & $15 \pm 11$ \\
\hline Pleural cavity cells & $<50$ & $<50$ & \\
\hline
\end{tabular}

* Results summarised from four experiments using normal male (two experiments) and female (two experiments) CBA/H mice (age range 1.5-5 months). In each experiment pooled tissues from four age- and sex-matched mice were used. Viable nucleated cells were determined by trypan blue exclusion. The average viable cell counts per organ \pm s.e.m. $\left(\times 10^{-6}\right)$ were: spleen $(62 \pm 11)$, thymus $(129 \pm 40)$, parathymic lymph nodes $(4.5 \pm 0.8)$, mesenteric lymph nodes $(13 \pm$ $0.6)$, popliteal lymph nodes $(0.9 \pm 0.25)$, bone marrow $(16 \pm 2.3$, per tibia and femur), Peyer's patches $(0.9 \pm 0.2)$, peritoneal cells $(2.6 \pm$ $0.5)$, and pleural cavity cells $(1.1 \pm 0.1)$.

$\uparrow \% \mathrm{BrM}=(\mathrm{BrM}$ PFC $/ \mathrm{Ig}$ PFC $) \times 100$

$\ddagger$ Arithmetic mean \pm s.e.m. for four experiments. 
Table 2 Proportion of Ig-secreting cells making BrM antibody after short-term culture*

\begin{tabular}{|c|c|c|c|c|c|}
\hline \multirow{2}{*}{$\begin{array}{l}\text { Experiment } \\
\text { no. }\end{array}$} & \multirow{2}{*}{$\begin{array}{l}\text { Days in } \\
\text { culture }\end{array}$} & & \multicolumn{2}{|c|}{$\begin{array}{c}\text { PFC per } 10^{6} \text { ori- } \\
\text { ginal } \\
\text { cultured cells }\end{array}$} & \multirow[b]{2}{*}{$\% \mathrm{BrM} \dagger$} \\
\hline & & & Ig & BrM & \\
\hline \multirow[t]{2}{*}{ 1. 6 week (female) } & 3 & Spleen & $65,000 \ddagger$ & $500 \ddagger$ & 0.8 \\
\hline & & $\begin{array}{l}\text { Peritoneal } \\
\text { cells }\end{array}$ & 15,000 & 6,000 & 40.0 \\
\hline \multirow[t]{2}{*}{ 2. 11 week (female) } & 2 & Spleen & 36,900 & 580 & 1.6 \\
\hline & & $\begin{array}{l}\text { Peritoneal } \\
\text { cells }\end{array}$ & 21,000 & 15,900 & 75.4 \\
\hline \multirow[t]{2}{*}{ 3. 14 week (female) } & 3 & $\begin{array}{l}\text { Peritoneal } \\
\text { cells }\end{array}$ & 28,200 & 24,400 & 86.5 \\
\hline & & Pleural cells & 25,600 & 16,000 & 66.4 \\
\hline $\begin{array}{l}\text { 4. Retired breeder } \\
\text { female }\end{array}$ & 2 & $\begin{array}{l}\text { Peritoneal } \\
\text { cells }\end{array}$ & 39,140 & 37,060 & 94.7 \\
\hline \multirow{2}{*}{$\begin{array}{l}\text { 5. Retired breeder } \\
\text { female }\end{array}$} & 3 & Spleen & 105,600 & 2,040 & 1.9 \\
\hline & & $\begin{array}{l}\text { Peyer's } \\
\text { patches }\end{array}$ & 20,800 & 34 & 0.16 \\
\hline
\end{tabular}

* Cells from CBA/H mice were cultured for several days in polyacrylamide dimple rafts ${ }^{22}$. Each raft contained $1-2 \times 10^{6}$ viable cells, $10 \mu \mathrm{g}$ LPS (from E. coli 0128:B12) in Eagles' minimal essential medium containing $10 \%$ fetal calf serum and $10^{-4} \mathrm{M}$ mercaptoethanol. For serous cavity cells high numbers of Ig and BrM PFC were evident at least by day 1 (data not shown).

$\dagger \% \mathrm{BrM}=(\mathrm{BrM}$ PFC $/$ Ig PFC $) \times 100$.

$\ddagger$ Mean PFC counts on duplicate or triplicate cultures. Percentage s.e. between cultures was $\leq 15 \%$.

in peritoneal cells) before culture abolishes the appearance of BrM PFC. Although this has little effect on Ig PFC in spleen, it causes a proportional or total removal of Ig PFC from peritoneal cell cultures. This result is consistent with the relatively low proportion of potential BrM PFC in spleen and the high proportion of potential BrM PFC in peritoneal cell populations.

It is clear from the present work that a high proportion of Ig-șecreting cells in normal mice are specific for BrM. Several lines of evidence indicate that this result is probably not unique. First, there are many reports showing that the incidence of autoantibodies is widespread amongst normal healthy individuals ${ }^{1-10}$. Second, Dresser ${ }^{20}$ has recently claimed that a high proportion of IgM-secreting cells in mouse spleen $(\sim 50 \%)$ are specific for antigens on isologous IgG. Third, it has been known for some time that a large percentage of Waldenstrom macroglobulins $(10-20 \%)$ possess autospecificity for human IgG (reviewed by Metzger ${ }^{21}$ ). These observations suggest that much of the 'natural' Ig synthesis of an animal (existing and potential) may be directed towards endogenous antigens. If this hypothesis is correct it has farreaching implications on the way we view the normal development and functioning of the immune system.

We thank Sue Fordham for assistance and Freda Sochasky for typing the manuscript. This work was supported in part by a grant to A.J.C. from the MRC of Canada.

\section{E. J. STEELE \\ A. J. CUnNingham}

Department of Microbiology,

John Curtin School of Medical Research,

Australian National Univeristy, Canberra, Australia

Received 28 February; accepted 6 June 1978.

Present address: Ontario Cancer Institute, 500 Sherbourne Street, Toronto, Ontario, Canada M4X $1 \mathrm{~K} 9$.

1. Arend, P. \& Nijssen, J. Nature 269, 255-257 (1977).

2. Milgrom, F., Dubiski, S. \& Woznicko, G., Vox. Sang. 1, 172-183 (1956)

3. Mandy, W. J., Fudenberg, H. H. \& Lewis, F. B. J. Immun. 95, 501-509 (1965).

4. Izui, S., Zaldivar, N. M., Scher, I. \& Lambert, P.-H. J. Immun. 119, 2151-2156 (1977)

5. Rosenthal, M. C. \& Schwartz, L. I. Proc. Soc. exp. Biol. 76, 635-638 (1951)

6. Dybkjaer, E. \& Kissmeyer-Nielsen, F. Vox. Sang. 12, 429-442 (1967).
7 Rosenberg, S. A. \& Rogentine, B. M. Nature new Biol. 239; 203-204 (1972).

8 Winchester, R. J., Fu, S. M., Winfield, J. B. \& Kunkel, H. G. J. Immun. 114, 410-414 (1975)

9. Cunningham, A. J. Transplant. Rev. 31, 23-43 (1976)

10. Cunningham, A. J. Nature 252, 749-751 (1974)

11. Cunningham, A. J. \& Szenberg, A. Immunology 14, 599-600 (1968).

12. Molinaro, G. A. \& Dray, S. Nature 248, 515-517 (1974).

13. Vyas, G. N., Fudenberg, H. H., Pretty, H. M. \& Gold, E. R. J. Immun. 100, 274-279 (1968)

14. Dresser, D. W. \& Popham, A. M. Nature 264, 552-554 (1976)

15. Moller, G. Transplant Rev. 23, 126-137 (1975).

16. Lord, E. M. \& Dutton, R. W. J. Immun. 115, 1199-1205 (1975)

17. Pages, J. \& Bussard, A. E. Nature 257, 316-317 (1975).

18. Lord, E. M. \& Dutton, R. W. J. Immun. 115, 1631-1635 (1975)

19. Nossal, G. J. V., Bussard, A. E., Lewis, H. \& Mazie, J. C. J. exp. Med. 131, 894-916 (1970).

20. Dresser, D. Nature 274, 480-483 (1978).

21. Metzger, H. In Tolerance, Autoimmunity and Aging (eds Sigel, M. M. \& Good, R. A. 120-126 (Charles C. Thomas, Springtield, Illinois, 1972).

22. Marbrook, J. \& Haskill, J. S. Cell. Immun. 13, 12-21 (1974).

\section{Identification of ataxia telangiectasia heterozygotes, a cancer prone population}

IN ataxia telangiectasia (AT), an autosomal recessive disease of man with neurological, cutaneous and immunological abnormalities ${ }^{1}$, cells from homozygotes are sensitive to ionising radiation $^{2}$ and have a low capacity to repair the resulting DNA damage $^{3}$. Heterozygotes lack the main clinical features of the syndrome but share with homozygotes a high predisposition to cancer ${ }^{4}$. One study has demonstrated an increased level of chromosomal abnormalities in some heterozygotes ${ }^{5}$. Because these heterozygotes represent $\geqslant 1 \%$ of the population ${ }^{4}$ and cannot be diagnosed clinically, their characterisation represents a major challenge in cancer epidemiology. We report here the laboratory identification of a series of obligate heterozygotes for AT, based on the sensitivity of lymphoblastoid cell lines to ionising radiation.

Peripheral blood lymphocytes were isolated' from five AT homozygotes, eight obligate heterozygotes, one clinically normal sibling of an AT homozygote and 11 controls. One aliquot of lymphocytes was transformed with Epstein-Barr

Table 1 DNA replication and repair in PHA-stimulated lymphocytes

\begin{tabular}{lccc}
\hline & $\begin{array}{c}\text { DNA } \\
\text { replication } \\
\text { (c.p.m. } \times 10^{-5} \\
\text { per }\end{array}$ & $\begin{array}{c}\text { DNA } \\
\text { repair } \\
\text { (c.p.m. } \times 10^{-3}\end{array}$ & \\
& $10^{6}$ cells $)$ & $10^{6}$ cells $)$ & $\begin{array}{c}\text { Normalised* } \\
\text { repair }\end{array}$ \\
Controls & $4.4 \pm 2.7$ & $6.1 \pm 0.8$ & 0.014 \\
AT heterozygotes & $5.8 \pm 3.1$ & $7.4 \pm 3.2$ & 0.013 \\
AT homozygotes & $2.7 \pm 0.7$ & $1.0 \pm 0.2$ & 0.004 \\
\hline
\end{tabular}

Peripheral blood lymphocytes from 11 controls, eight heterozygotes and five homozygotes were separated by sedimentation on methyl cellulose ${ }^{6}$, and plated in medium (F15, Gibco) supplemented with $15 \%$ fetal calf serum, penicillin $\left(10^{5} \mathrm{U}^{-1}\right)$, streptomycin $\left(60 \mathrm{mg} \mathrm{l}^{-1}\right)$, and $1 \%$ PHA (v/v, Gibco). DNA replication was determined on day 4 after addition of PHA by measurement of incorporation of ${ }^{3} \mathrm{H}$-thymidine (Amersham, $25 \mathrm{Ci} \mathrm{mmol}^{-1}, 5 \mu \mathrm{Ci} \mathrm{ml}^{-1}$ ) into DNA precipitated with $5 \%$ trichloroacetic acid and filtered. DNA repair was determined at the same time by irradiating cells in a Gamma Cell 220 (Atomic Energy of Canada Ltd) with $40 \mathrm{krad}$, at $6.5 \mathrm{krad} \mathrm{min}^{-1}$. Repair synthesis was measured in the presence of $10 \mathrm{mM}$ hydroxyurea as described previously ${ }^{10}$. Replication and repair are given as mean \pm 1 s.d. Homozygotes used in this study have been designated AT1ABR through AT5ABR. This notation replaces AT1-AT4 which was used previously for the first four AT homozygotes ${ }^{11}$. The replication value for AT3ABR (AT3), which is approximately an order of magnitude lower than that for the other AT homozygotes ${ }^{11}$, has not been included.

* Normalised repair refers to the ratio of DNA repair to DNA replication when the latter is normalised to $5 \times 10^{5} \mathrm{c} . \mathrm{p} . \mathrm{m}$. This ratio has been found to remain constant for a given lymphocyte population from day 3 to day 5 after addition of PHA (unpublished observations). 